\title{
Histological Observations on the Responses of Pine Species, Pinus strobus and P. taeda, Resistant to Bursaphelenchus xylophilus Infection
}

\author{
Toshihiro YAMADA* and Shin-ichiro ITO**
}

\begin{abstract}
Bursaphelenchus xylophilus was inoculated into the branches of wilt-resistant Pinus taeda and $P$. strobus, and wilt-susceptible $P$. thunbergii. The histology of inoculated pine branches was investigated. Nematode numbers increased in whole inoculated branches of $P$. thunbergii. Nematode numbers decreased in those of resistant species, except in proxim. ity to the inoculation site of $P$. taeda. Histological changes were delayed in the cortex and phloem tissue and cambium of $P$. thunbergii inoculated branches. In resistant species, necrosis and destruction of cortex and phloem tissue and cambium ( $P$. taeda) or occlusion of cortical resin canal ( $P$. strobus) occurred near the inoculation site rapidly after nematode inoculation. Wound periderm was formed within 3 weeks and 5 weeks after inoculation in $P$. taeda and $P$. strobus, respectively. Wound periderm formation was observed only around the cortical resin canals in $P$. thunbergii. Necrosis of xylem parenchyma was conspicuous in $P$. thunbergii, but not in resistant species. These results suggest that responses of resistant species, wound periderm formation and occlusion of cortical resin canal, trapped the nematode within damaged tissue. It is also suggested that insensitivity of xylem parenchyma to nematode infection acts as a defensive factor.
\end{abstract}

(Received March 31, 1993)

Key words: Bursaphelenchus xylophilus, histology, nematodes, pine wilt disease, Pinus spp., resistance.

\section{INTRODUCTION}

Native Japanese black (Pinus thunbergii Parl.) and Japanese red ( $P$. densiflora Sieb. et Zucc.) pines are susceptible and loblloly pine $(P$. taeda L.) and eastern while pine $(P$. strobus $\mathrm{L}$.) are resistant to infection by pinewood nematode, Bursaphelenchus xylophilus (Steiner et Buhrer) Nickle. Such relative resistance to $B$. xylophilus infection among pine species have been well documented by several researchers ${ }^{1,3,5,8,9,13)}$.

Several histological or chemical investigations suggested that dynamic responses contributed to the resistance mechanisms. Wound periderm formation was observed in pine trees inoculated with the nematode, including $P$. strobus, which had not wilted ${ }^{10,11}$. Dynamic responses were suggested to contribute to the resistance mechanisms of rigitaeda pine $(P \text {. rigida } \times P \text {. taeda })^{12}$. In a histochemical study, host responses occurred rapidly in the cortex and phloem of resistant species $P$. strobus, while these responses were delayed in a susceptible species, $P$. thunbergii ${ }^{14}$. In the previous report, we found several phenomena in the responses of resistant species, and reported the differences in the responses of stem between P. taeda and $P$. strobus ${ }^{6}$.

To reveal the resistant responses, we have investigated the histological changes in nematode-

\footnotetext{
- Forestry and Forest Products Research Institute (FFPRI), Ibaraki 305, Japan

** Kansai Research Center, FFPRI, Kyoto 612, Japan 森林総合研究所関西支所
} 


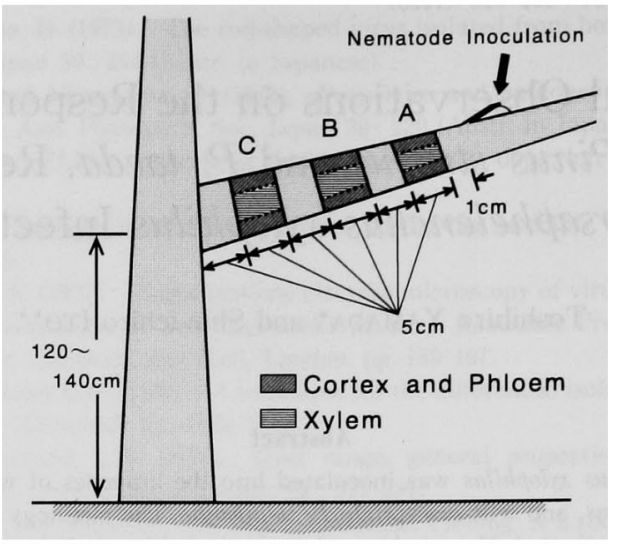

Fig. 1. Diagram showing nematode inoculation and sampling.

inoculated branches of pines, resistant species $P$. taeda and $P$. strobus in comparison with the susceptible species $P$. thunbergii.

\section{MATERIALS AND METHODS}

Inoculation and sampling. Nematodes used for inoculum, B. xylophilus (isolate S-10) were reared on Botrytis cinerea Pers. Four-year-old $P$. taeda, seven-year-old $P$. strobus, and eight-year-old $P$. thunbergii trees were grown at the nurseries of the Kansai Research Center, Forestry and Forest Products Research Institute. On August 10th, 1988, five thousand B. xylophilus were introduced into each cut wound on two branches of each pine tree. Then, the inoculation sites were wrapped with parafilm. Branches of three inoculated trees and one uninoculated tree were cut-off at 1,2, and 3 weeks after inoculation. Branches of two inoculated trees were cut-off 5 weeks after inoculation. The branches were then divided into 3 portions, $\mathrm{A}, \mathrm{B}$, and $\mathrm{C}$ as shown in Fig. 1 .

Nematode extraction and anatomy. Nematodes were isolated by a Baerman funnel method, and the number of nematodes were counted. For the histological observation, tissue samples from each portion were fixed in FAA (formalin-acetic acid-50\% ethanol, $15: 5: 200$ ), dehydrated in alcohol series, and embedded in paraffin. Sections of $c a .20 \mu \mathrm{m}$ in thickness were made with a sledge microtome and double-stained with safranin and fast green to observe microscopically.

\section{RESULTS AND DISCUSSION}

\section{Development of the disease in whole tree}

The two-year-old needles of $P$. thunbergii began to yellow 4 weeks after inoculation. The needles generally discolored and the trees wilted, 5 and 6 weeks following inoculation, respectively. No visible symptoms were observed in $P$. taeda and $P$. strobus until 5 weeks after inoculation. Until the end of the inoculated year, a few inoculated branches of $P$. taeda died, but $P$. strobus displayed neither dead branches nor dead trees.

\section{Distribution of nematodes}

Nematode numbers increased in the proximity of inoculation site, portion A, of $P$. taeda, but did not increase apart from the inoculation site, at portion B and C (Fig. 2a). In whole inoculated branches of $P$. strobus, the nematode numbers were as high as those of $P$. thunbergii up to one week after inoculation, but then decreased gradually (Fig. 2b). Nematode numbers increased in whole inoculated branches of $P$. thunbergii (Fig. 2c). 

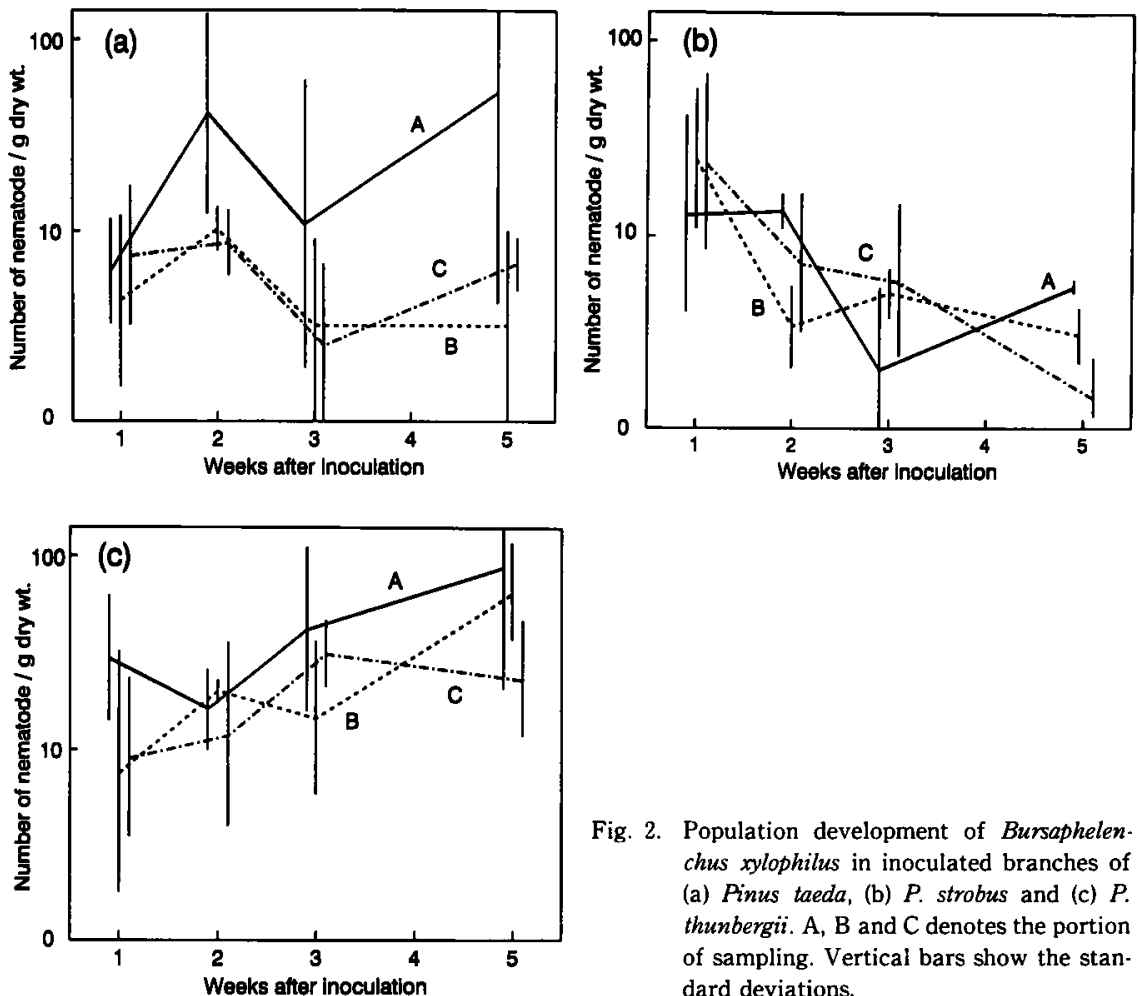

Fig. 2. Population development of Bursaphelen chus xylophilus in inoculated branches of (a) Pinus taeda, (b) P. strobus and (c) $P$. thunbergii. $\mathrm{A}, \mathrm{B}$ and $\mathrm{C}$ denotes the portion of sampling. Vertical bars show the standard deviations.

Table 1. Necrosis and destruction of cortex, phloem and cambium of B. xylophilus-inoculated Pinus spp.

\begin{tabular}{|c|c|c|c|c|c|c|c|c|c|c|c|c|c|}
\hline \multirow[t]{2}{*}{ Species } & \multirow[t]{2}{*}{ Portion } & \multicolumn{4}{|c|}{$\begin{array}{l}\text { Destruction of cortex } \\
\text { epithelial cell }\end{array}$} & \multicolumn{4}{|c|}{$\begin{array}{l}\text { Necrosis/destruction } \\
\text { of cortex and phloem }\end{array}$} & \multicolumn{4}{|c|}{$\begin{array}{c}\text { Necrosis/cavity formation } \\
\text { at cambium }\end{array}$} \\
\hline & & $1^{\theta\}}$ & 2 & 3 & 5 & $1^{\mathbf{8})}$ & 2 & 3 & 5 & $1^{\text {a) }}$ & 2 & 3 & 5 \\
\hline \multirow[t]{3}{*}{ P. taeda } & $\mathrm{A}$ & $+b)$ & $+t$ & $+t$ & ++ & $\pm^{0)}$ & + & ++ & $+t$ & $-b_{1}$ & + & + & \pm \\
\hline & B & + & ++ & ++ & ++ & - & + & + & + & - & \pm & - & - \\
\hline & $\mathrm{C}$ & + & ++ & ++ & + & - & \pm & ++ & + & - & \pm & \pm & - \\
\hline \multirow[t]{3}{*}{ P. strobus } & A & + & + & + & + & \pm & \pm & \pm & + & - & - & - & - \\
\hline & $\mathrm{B}$ & + & + & + & + & \pm & \pm & - & + & - & - & - & - \\
\hline & $\mathrm{C}$ & + & + & + & + & \pm & \pm & - & + & - & - & - & - \\
\hline \multirow[t]{3}{*}{ P. thunbergii } & A & + & ++ & ++ & ++ & \pm & \pm & + & ++ & - & - & \pm & ++ \\
\hline & $\mathrm{B}$ & + & $+t$ & ++ & ++ & - & - & \pm & ++ & - & - & \pm & ++ \\
\hline & $\mathrm{C}$ & + & ++ & ++ & ++ & - & - & \pm & + & - & - & - & \pm \\
\hline
\end{tabular}

a) Weeks after inoculation.

b) - : absent, \pm : slightly visible,,+++ : increasingly conspicuous.

\section{Necrosis and destruction of cortex and phloem tissue and cambium}

One week after inoculation, destruction of epithelia lining the cortical resin canals was observed in all species (Table 1, Plate I-1). Two weeks after inoculation, destruction of cortex and phloem tissue and cambium in $P$. taeda had already occurred (Plate I-2,3). Histological changes, other than destruction of epithelia, were not observed until 2 weeks after inoculation in cortex and phloem of $P$. thunbergii. Necrosis and destruction of cortex and phloem tissue was most conspicuous in $P$. taeda, but was the least 
Table 2. Protective tissue formation in cortex and phloem of B. xylophilus-inoculated Pinus spp.

\begin{tabular}{|c|c|c|c|c|c|c|c|c|c|c|c|c|c|}
\hline \multirow[t]{2}{*}{ Species } & \multirow[t]{2}{*}{ Portion } & \multicolumn{4}{|c|}{$\begin{array}{l}\text { Wound periderm } \\
\text { formation }\end{array}$} & \multicolumn{4}{|c|}{$\begin{array}{l}\text { Wound periderm formation } \\
\text { around resin canal }\end{array}$} & \multicolumn{4}{|c|}{$\begin{array}{c}\text { Occlusion of resin } \\
\text { canal }\end{array}$} \\
\hline & & $1^{9)}$ & 2 & 3 & 5 & $1^{\text {a) }}$ & 2 & 3 & 5 & $1^{\text {a) }}$ & 2 & 3 & 5 \\
\hline \multirow[t]{3}{*}{ P. taeda } & A & $-b)$ & - & + & ++ & $-6)$ & - & + & + & $\pm^{b)}$ & + & + & \pm \\
\hline & B & - & - & \pm & ++ & - & - & \pm & ++ & - & \pm & \pm & + \\
\hline & $\mathrm{C}$ & - & - & \pm & ++ & - & - & - & ++ & - & \pm & \pm & \pm \\
\hline \multirow[t]{3}{*}{$P$. strobus } & $A$ & - & - & - & + & - & - & - & ++ & \pm & + & + & ++ \\
\hline & B & - & - & - & + & - & - & - & ++ & \pm & + & + & ++ \\
\hline & C & - & - & - & + & - & - & \pm & ++ & \pm & \pm & + & + \\
\hline \multirow[t]{3}{*}{ P. thunbergii } & A & - & - & - & \pm & - & - & \pm & - & \pm & \pm & + & - \\
\hline & B & - & - & - & - & - & - & + & + & \pm & \pm & + & + \\
\hline & $\mathrm{C}$ & - & - & - & - & - & - & + & + & - & - & \pm & - \\
\hline
\end{tabular}

a) Weeks after inoculation.

b) - : absent, \pm : slightly visible,,+++ : increasingly conspicuous.

apparent in susceptible $P$. thunbergii, until 3 weeks after inoculation. Cavity formation and cell necrosis were observed in the cambium of $P$. taeda near the inoculation site, portion A, within 2 weeks after inoculation (Table 1). Fewer cavities, however, were observed in the distal portion. Cambial death did not develop in $P$. strobus. Breakdown of $P$. thunbergii cortex and phloem tissue became conspicuous, and advanced cambial death was observed 3 weeks after inoculation. Many nematodes distributed in destroyed cortex and phloem tissue and cavities at cambia, especially of $P$. taeda (Plate I-2, 3).

\section{Responses in the cortex and phloem}

Wound periderms were well developed in P. taeda 3 weeks after inoculation (Plate I-4), and also in $P$. strobus within 5 weeks, but not formed in $P$. thunbergii except for the periderms surroundig cortical resin canals (Table 2). In all species, wound periderms were formed around cortical resin canal, when cortex epithelial cells were destroyed and necrosis developed in the encircling parenchyma cells (Plate I-5). However, frequency and the degree of wound periderm formation around the resin canal was lower in $P$. thunbergii than that in $P$. taeda and $P$. strobus. Occlusion of cortical resin canal, resulted from the hypertrophy of parenchyma cells and hyperplasia of epithelial cells, became gradually conspicuous in inoculated $P$. strobus (Plate I-6a, b). Occlusion of cortical resin canal and wound periderm formation did not inhibit the initial migration of nematodes. However, they would become effective to trap the nematodes within damaged tissue after their development.

Rapid tissue discoloration was reported in $P$. strobus after the inoculation of $B$. xylophilus ${ }^{10.11}$. Moreover, death of the inner bark tissue and cambium was restricted in parts of trees and no mortality of whole tree was observed in $P$. strobus ${ }^{3,14)}$. The findings of Tamura et al. suggest that histochemically detectable responses occur rapidly in $P$. strobus, despite of low degree of cortex and phloem tissue destruction $^{(4)}$. Lesser death in $P$. strobus cortex and phloem may cause delayed wound periderm formation. If localized death of cortex and phloem occurred in $P$. strobus, wound periderm wound be formed more rapidly.

Restriction of nematode dense area observed in $P$. taeda corresponded to rapid necrosis and destruction of cortex and phloem tissue and the following wound periderm formation near the inoculation site. Reproduction of dispersed nematodes was not observed in the inoculated branche of $P$. taeda and $P$. strobus. These results suggest that localized death in the cortex and phloem tissue of resistant species, especially of $P$. taeda, results from the excessive response to the invasion of $B$. xylophilus, and concerns with the resistance.

\section{Changes in the xylem}

One week after inoculation, epithelium destruction and parenchyma discoloration and necrosis were rarely observed in the xylem of any species (Table 3 ). Then, only in $P$. thunbergii, these changes became widespread in the inoculated branches, and most of parenchyma had been dead by 5 weeks after inoculation. A high number of xylem ray parenchyma cells became necrotic in $P$. thunbergii before the 
Table 3. Necrosis and destruction of B. xylophilus-inoculated Pinus spp. xylem

\begin{tabular}{|c|c|c|c|c|c|c|c|c|c|}
\hline \multirow{2}{*}{ Species } & \multirow{2}{*}{ Portion } & \multicolumn{4}{|c|}{ Destruction of epithelial cell } & \multicolumn{4}{|c|}{ Necrosis of parenchyma cell } \\
\hline & & $1^{\text {a) }}$ & 2 & 3 & 5 & $1^{\text {a) }}$ & 2 & 3 & 5 \\
\hline \multirow[t]{3}{*}{ P. taeda } & A & $-b)$ & + & + & \pm & - b) & \pm & \pm & + \\
\hline & B & - & - & \pm & \pm & - & \pm & \pm & \pm \\
\hline & $\mathrm{C}$ & - & - & \pm & \pm & - & \pm & \pm & \pm \\
\hline \multirow[t]{3}{*}{$P$. strobus } & A & \pm & - & \pm & + & \pm & \pm & - & \pm \\
\hline & B & - & - & \pm & \pm & \pm & \pm & - & \pm \\
\hline & $\mathrm{C}$ & - & - & \pm & \pm & \pm & \pm & - & \pm \\
\hline \multirow[t]{3}{*}{ P. thunbergii } & A & - & \pm & + & + & - & + & + & ++ \\
\hline & B & - & + & \pm & + & - & + & + & ++ \\
\hline & $\mathrm{C}$ & - & + & \pm & + & - & \pm & \pm & ++ \\
\hline
\end{tabular}

a) Weeks after inoculation.

b) -: absent, \pm : slightly visible,,+++ : increasingly conspicuous.

cambial death (Table 1,3). In $P$. taeda xylem, destruction of epithelial cells and necrosis of parenchyma cells, following the destruction of cortex and phloem tissue and cambium, were found proximal to the inoculation site, portion $\mathrm{A}$, and were still infrequent in the distal portion. In spite of conspicuous destruction of cortex and phloem tissue and cambium, few xylem parenchyma cells died before cambial death in $P$. taeda.

Water deficit is an important factor responsible for whole tree mortality in susceptible species ${ }^{4,7}$. Physiological changes in xylem parenchyma which cause cavitation are closely related to the denaturation of xylem parenchyma ${ }^{2}$, and therefore possibly related to the final death of xylem parenchyma. Death of xylem parenchyma preceded death of cortex and phloem tissue in inoculated branches of susceptible species. This suggests that xylem dysfunction finally induce cambial death in susceptible species.

In the previous studies, cavitation was found only in limited portion of $P$. taeda stem ${ }^{6}$ and of inoculated branches of $P$. strobus ${ }^{14}$. Substances which cause tracheid cavitation and progressive water blockage might not increase in the stem of resistant species for the insensitivity of xylem parenchyma to nematode activities ${ }^{6}$. In the present study, death of xylem parenchyma was less in inoculated branches of $P$. taeda and $P$. strobus than those in susceptible species, while cortex and phloem tissue of inoculated branches of $P$. taeda were destroyed in the early stage. These histological observations also suggest that insensitivity of xylem parenchyma to nematode infection contribute to the wilt resistance of Pinus spp. Localized death of cortex and phloem tissue and cambium appears to induce the following localized death of xylem parenchyma in inoculated branches of resistant species, especially of $P$. taeda. Further investigation on the chemical factors associated with localized death of cambium and insensitivity of xylem parenchyma observed in resistant species will be necessary to reveal the resistance mechanisms.

We wish to thank Dr. R.F. Myers, State University of New Jersey, U.S.A., Dr. H. Tamura and Dr. K. Kuroda. FFPRI, for their critical reading of the manuscript.

\section{Literature cited}

1. Dropkin, V.H. and Foudin, A.S. (1979). Report of the occurrence of Bursaphelenchus lignicolus-induced pine wilt disease in Missouri. Plant. Dis. 63 : 904-905.

2. Fukuda, K., Hogetsu, T. and Suzuki, K. (1992). Cavitation and cytological changes in xylem of pine seedling inoculated with virulent and avirulent isolates of Bursaphelenchus xylophilus and B. mucronatus. J. Jpn. For. Soc. $74: 289-299$.

3. Futai, K. and Furuno, T. (1979). The variety of resistances among pine-species to pine wood nematode, Bursaphelenchus lignicolus. Bull. Kyoto Univ. Forests $51: 23-36$ (in Japanese with English summary).

4. Ikeda, T. and Suzaki, T. (1984). Influence of pine-wood nematodes on hydraulic conductivity and water status in Pinus thunbergii. J. Jpn. For. Soc. 66: 412-420. 
5. Kiyohara, T. and Tokushige, Y. (1971). Inoculation experiments of a nematode, Bursaphelenchus sp., onto pine trees. J. Jpn. For. Soc. $53: 210-218$ (in Japanese with English summary).

6. Kuroda, K., Yamada, T. and Ito, S. (1991). Bursaphelenchus xylophilus induced pine wilt: Factors associated with resistance. Eur. J. For. Pathol. $21: 430-438$.

7. Kuroda, K., Yamada, T., Mineo, K. and Tamura, H. (1988). Effects of cavitation on the development of pine wilt disease caused by Bursaphelenchus xylophilus. Ann. Phytopath. Soc. Japan 54 : 606-615.

8. Linit, M.J. and Tamura, H. (1987). Relative susceptibility of four pine species to infection by pinewood nematode. J. Nematol. $19: 44-50$.

9. Myers, R.F. (1982). Susceptibility of pines to pinewood nematode in New Jersey. In Proceedings 1982 National Pine Wilt Disease Workshop (Appleby, J.E. and Malek, R.B. eds.). Illinois Department of Energy and Natural Resources. pp. 38-46.

10. Myers, R.F. (1984). Comparative histology and pathology in conifers infected with pine wood nematode, Bursaphelenchus xylophilus. In Proceedings of the United States-Japan Seminar. The Resistance Mechanisms of Pines Against Pine Wilt Disease (Dropkin, V. ed.). University of Missouri, Columbia. pp. 91-95.

11. Myers, R.F. (1986). Cambium destruction in conifers caused by pinewood nematodes. J. Nematol. $18: 398^{-}$ 402.

12. Oku, H., Shiraishi, T. and Chikamatsu, K. (1989). Active defense as a mechanism of resistance in pine against pine wilt disease. Ann. Phytopath. Soc. Japan 55: 603-608.

13. Tamura, H. and Dropkin, V.H. (1984). Resistance of pine trees to pine wilt caused by the nematode, Bursaphelenchus xylophilus. J. Jpn. For. Soc. 66 : 306-312.

14. Tamura, H., Yamada, T. and Mineo, K. (1988). Host responses and nematode distribution in Pinus strobus and $P$. densiflora infected with the pine wood nematode, Bursaphelenchus xylophilus. Ann. Phytopath. Soc. Japan 54 : 327-331.

\section{和 文 摘 要}

山田利博·伊藤進一郎：マッノザイセンチュウ感染に対する材線虫抵抗性マツ,テーダマツおよびストロープマツの 反応の組織学的観察

マツノザイセンチュウを感受性のクロマツ，抵抗性のテーダマツおよびストローブマツの枝に接種し接種枝の解剖 観察を行った。線虫数はクロマツでは枝全体で增加したが, 抵抗性種ではテータマツの接種部近傍を除き次第に減少し た。クロマツの皮層, 師部や形成層では病変の現れるのが遅かったが, 抵抗性種では早くから, 皮層, 師部や形成層の 壊死·破壊, 皮層樹脂道の閉塞がみられた。傷害周皮の形成はテーダマツで接種 3 週後,ストロープマツて 5 週後にみ られたが,クロマツでは殆どなかった。部柔組織の壊死はクロマツでは影著であったのに対し, 抵抗性锺では少なか つた。傷害周皮形成および皮層樹脂道の閉塞, 線虫加害に対する木部の感受性の低さが抵抗性要因として働くことが示 唆された。

\section{Explanation of plate}

\section{Plate I}

1. Breakdown of cortex epithelial cells (arrows) in $P$. thunbergii. Bar represents $200 \mu \mathrm{m}$.

2. Cavity formation (arrows) at cambium of $P$. taeda. Bar represents $100 \mu \mathrm{m}$.

3. Destruction of $P$. taeda cortex tissue. Arrow indicates the invasion of the cortex tissue by the nematode and cavity formation. Bar represents $100 \mu \mathrm{m}$.

4. Wound periderm (arrow) formation around the necrotic tissue of P. taeda cortex and phloem. Bar represents $200 \mu \mathrm{m}$.

5. Wound periderm (arrow) formation in $P$, thunbergii encircling the cortical resin canal. Bar represents $200 \mu \mathrm{m}$.

6. Hyperplasia of cortex epithelial cells (arrows) (a, b) and occlusion of cortical resin canal (b) of $P$. strobus. Bars represent $100 \mu \mathrm{m}$. 
Plate I
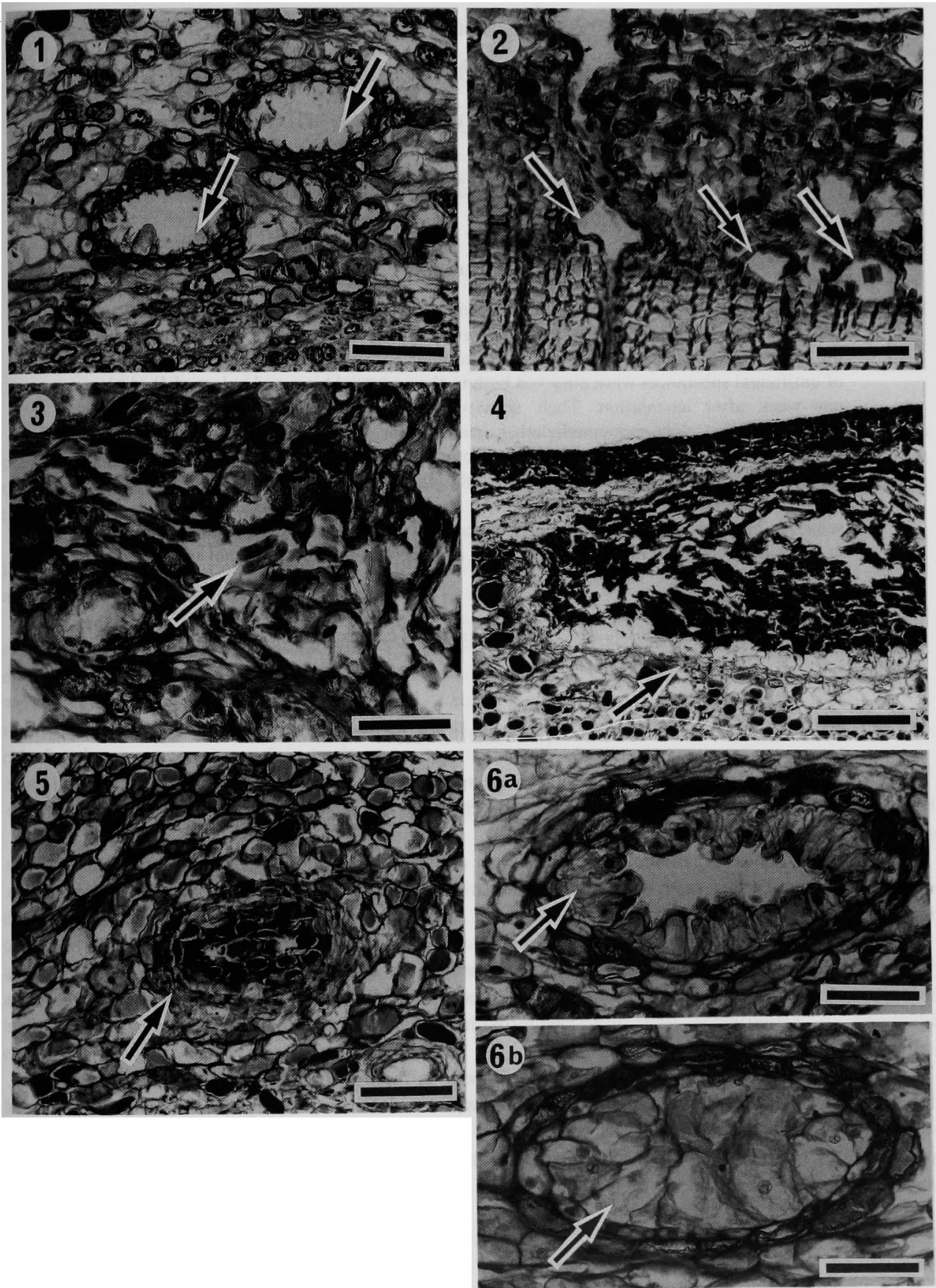